\title{
Strach a školní výkon
}

\section{Isabella Pavelková, Kateřina Kubíková, Aneta Boháčová}

\begin{abstract}
Abstrakt: Článek uvádi do problematiky strachu, predevšim se soustreduje na vztah mezi žákovským strachem a školním výkonem, respektive na dopady strachu na učení. Analyzovány jsou jednak strukturálni prístupy ke strachu a testové úzkosti (komponenty strachu), jednak procesuálni prístupy. Vènujeme se modelìm interference a modelìm deficitu, ale i otázkám úzkosti $v$ procesu učeni, osobnosti úzkostného žáka, diferenciaci strachu na facilitujici a inhibujici. Pozornost je sméřvována na hodnoceni (zpracováni) strachu jedincem. Řešenou kličovou otázkou je, nakolik strach posiluje, respektive oslabuje školni výkon. Okrajově se zabýváme i konstrukty souvisejicimi se strachem: motivačnè-volními charakteristikami žákü.
\end{abstract}

Klíčová slova: pedagogická psychologie, strach a úzkost, testová úzkost, komponenty strachu, strach a učeni, motivace.

\section{ÚvoD}

Strach a úzkost bývají se školou velmi často spojovány jak v laických kruzích, tak u odborníků. I dnes se často setkáváme $s$ velmi zjednodušeným uchopením tohoto problému a proklamativními, černobílými vyjádřeními typu: „Strach do školy v žádném případě nepatřrí. Přesto se $s$ ním ve škole setkáváme - a někdy na nečekaných místech. Fenoménu „skolního strachu“ je sice věnována relativně velká pozornost, existuje zde však mnoho nedořešených otázek, a to nejen z hlediska podob strachu a situací vyvolávajících strach, dopadů strachu na výkon, ale i z hlediska možností diagnostiky strachu a copingových strategií, jak se se strachem vyrovnávat.

Lidské úzkosti a strachu se dlouhodobě věnuje mnoho vědních disciplín, především psychologie (úzkost je velkým tématem např́klad v psychoanalýze, vývojová psychologie hovoří o separační úzkosti a podobně) a filosofie (zejména existenciální filosofie; Kierkegaard - úzkost ze smrti, Heidegger - úzkost z nicoty), ale se strachem se často pracuje i v literatuře (Camus, Kafka a mnoho dalších). V příspěvku se pokusíme toto široké téma zúžit na některé vybrané otázky žákovského strachu.

$\mathrm{V}$ češtině, podobně jako $\mathrm{v}$ jiných jazycích, je rozlišován pojem strach a úzkost. Rozlišení mezi nimi však není u většiny autorů ostré. $\mathrm{V}$ případě úzkosti i strachu jde o reakci na nebezpečí (Lazarus, 1991). Strach bývá většinou definován jako „signální emoce“, která se váže na určitý předmět (jev či situaci), který je považován za ohrožující. Obdobnou emocí je úzkost, 
ale ta mívá neurčitý předmět, je difuzní, jde o obavu z něčeho neurčitého (nespecifický pocit hrozby). O pocit hrozby jde tedy jak u strachu, tak u úzkosti. U úzkosti však jde vedle napětí často i o pocit určité bezradnosti a paniky. Úzkost bývá prožívána tíživěji než strach, protože očekávání nemilé události je často horší než událost sama, těžko se v takové situaci orientujeme (Drvota \& Plzák, 1971; Honzák, 1995; Vymětal, 2004). Shoda je v tom, že mezi strachem a úzkostí neexistuje přesná hranice a tyto pojmy nelze od sebe striktně oddělovat. Úzkost a strach se pravděpodobně podmiňují, úzkost často přechází ve strach a naopak. Ve stati nebudeme striktně rozlišovat mezi termínem strach a úzkost. V popisu českých i zahraničních zdrojů používáme pojmy strach a úzkost, jak jsou autory prací užívány.

\section{UVEDENÍ DO PROBLEMATIKY STRACHU (ÚZKOSTI)}

Patř́ úzkost a strach do našeho života? Honzák (1995) zdůrazňuje, že úzkost i strach jsou přirozenou součástí života jedince, podílí se na jeho přežití. Upozorňují nás na hrozící nebezpečí - mají signalizační funkci. To, jak se jedinec v situaci vyvolávající strach projevuje a jak ji prožívá, vnímá a hodnotí, závisí na osobnosti jedince (míra rysové úzkostnosti u jedince), velikosti podnětu (situaci), předchozích zkušenostech a copingových strategiích jedince. Tendence prožívat strach v různých situacích je tedy individuální. U úzkostných jedinců nastupuje strach daleko rychleji již při menším reálném ohrožení. Při silném ohrožení (přepadení, maturitní zkouška a podobně) se rozdíly do jisté míry „stírají“ - strach mají skoro všichni. Důležité je tedy rozlišení mezi stavem strachu a strachem jako osobnostním rysem (Hagtvet, 1989), úzkostnost jako osobnostní rys bývá relativně trvalá vlastnost. Stav strachu mohou vyvolávat jak vnější podněty či situace (zkouška, výhrůžka, nezvladatelný úkol, fyzické ohrožení), tak vnitřní podněty, vzpomínky či očekávání ohrožující situace (Vymětal, 2004). Výsledný stav je nepř́ijemný, s redukcí úzkosti přichází úleva.

Stavy úzkosti jsou úzce propojeny $s$ funkcemi vegetativní nervové soustavy a bývají doprovázeny výraznými fyziologickými změnami (zvýšení krevního tlaku, zrychlení pulzu, pocení, žaludeční nevolnost a podobně). Chování člověka je často motivováno snahou odstranit úzkost (redukovat tenzi). Př́i diagnostice úzkosti je většinou využíváno somatické dimenze (typickými znaky jsou: přerušovaný a neklidný spánek, zažívací problémy, bolesti hlavy, bolesti zad) a psychické dimenze (únava, nedůvěra $\mathrm{v}$ sebe, přecitlivělost, neklid). Ve svém životě zažíváme stavy, kdy je dobré mít určitý strach. Ten nás udrží pozorné a motivuje nás (aktivuje nás). Zkušenost míváme i s oslabujícím strachem (nemůžeme se soustředit, zapomínáme). Rozlišován bývá také reálný a nereálný strach (Vymětal, 2004). Zaměříme-li se na kontext školního prostředí, pak za reálný strach bychom mohli považovat situaci, kdy se dítě bojí zkoušení v př́padě, že se neučilo a danou látku neumí. Nereálný strach mívá iracionální, nepochopitelné 
či nepřiměřené charakteristiky: žák látku umí, připravoval se na zkoušení, a přesto se zkoušení silně obává a má nepřiměřenou trému.

\section{STRACH A ŠKOLNí VÝKON}

Při úvahách o školním strachu a možnostech jeho diagnostiky, respektive zvládání, je nutné respektovat to, že jde pravděpodobně o multidimenzionální konstrukt (Hembree, 1988; Hodapp, Glanzmann \& Laux, 1995; Pavelková, 2002; Sarason, 1984; Stöber, 2004). Zároveň je nutné respektovat velkou komplikovanost a specifičnost školního prostředí. Mimo jiné proto, že jde velmi často o hodnoticí situace, kde svou roli sehrává i obtížnost úkolů, vnímaná osobní zdatnost, „závazek žáků $\mathrm{k}$ učení", zaujetí úkolem a další motivačně volní charakteristiky žáka.

Strach $\mathrm{v}$ mírné podobě většinou zvyšuje výkon žáků, v silné podobě naopak výkon zeslabuje (Hagtvet, Man \& Sharma, 2001; Man \& Hrabal, 1989). Musíme však diferencovat mezi žáky úzkostnými, se silně vyvinutou potřebou bezpečí, kteří se do stavu frustrace dostávají velmi rychle a prožívají strach intenzivněji, a mezi jedinci neúzkostnými. Úzkostní lidé bývají vysoce citliví na sociální hodnocení. Úzkostní žáci považují hodnocení za objekt evaluace své osoby a svých schopností, a ne vynaloženého úsilí. Toto zjištění se naopak nepotvrdilo u neúzkostných osob, jež vnímaly hodnocení jako reakci na svůj výkon v úloze (Wine, 1971).

Úzkost prožívaná ve výkonových situacích bývá rozdělována na dva druhy: testová úzkost a sociální úzkost. Testová úzkost zahrnuje emoce vztahující se na všechny druhy výkonových situací, kdy jedinec očekává, že bude hodnocen (charakteristické především pro školu). Sociální úzkost má více podob, mívá obecnější charakter a týká se různých druhů výkonových činností. Projevuje se např. plachostí, rozpaky, studem a trémou. Plachý jedinec se necítí dobře v sociálních situacích, je sociálně neobratný. Silnějším projevem jsou pak rozpaky, které bývají doprovázeny fyziologickými projevy (červenáním, pocením, nejistotou v jednání apod.). Stydlivý jedinec prožívá zvýšenou zodpovědnost za vlastní výsledky a za nedostatky ve svých schopnostech. Jedinci trpící trémou mívají zvýšenou úzkost $\mathrm{z}$ publika (např. při mluvení před publikem, ústním zkoušením, přednesu referátu). Testová úzkost i sociální úzkost se podílí na prožívání strachu ve školním prostředí. Sociální úzkost je spíše obecná a je spojena s různými druhy výkonových činností. Testová úzkost se týká pouze jednoho druhu výkonové činnosti.

$\mathrm{V}$ dalším textu se budeme věnovat především testové úzkosti. Testovou úzkostí se začali zabývat Mandler a Sarason (1952), kteří se zaměřili na rozdíly ve výkonech jedinců v testové situaci. Rozdíly interpretovali na základě naučených psychických postupů (tzv. drivů). Někteří respondenti se zaměrovali na chování, které umožňuje úkol dokončit, a tím redukovali úzkost. Jiní se více zaměřovali na sebe než na úkol. Jedinci zaměření na sebe vykazovali $\mathrm{k}$ úkolu irelevantní jednání, které se může projevit pocity nedostatečnosti, 
bezmoci, ale také zvýšenými somatickými reakcemi, očekáváním trestu nebo ztrátou statusu a úcty, a je následně doprovázeno implicitními pokusy opustit testovou situaci. V testové situaci potom tyto skutečnosti vedou $\mathrm{k}$ narušení výkonu jedince a interferují s dokončením úkolu (Hembree, 1988). Dvěma druhům chování ve vztahu $\mathrm{k}$ úkolům (chování $\mathrm{k}$ úkolu relevantnímu a chování $\mathrm{k}$ úkolu irelevantnímu) se věnovali také Alpert a Haber (1960). Ve své teorii mluví o facilitující úzkosti (facilitating anxiety) a oslabující úzkosti (debilitating anxiety). Facilitující úzkost je spojena $s$ efektivnější prací na úkolech, mobilizuje síly, zatímco oslabující úzkost má rušivý vliv na výkon, brání jedinci v dobrém výkonu.

Testová úzkost byla ve svých raných koncepcích tematizována jako jednodimenzionální konstrukt. Od 70. let minulého století (Liebert \& Morris, 1967) jsou rozlišovány dvě hlavní komponenty testové úzkosti: obavy a emocionalita. Obavy (worry) představují kognitivní komponentu úzkosti. Může jít o obavy (vtíravé myšlenky) vztahující se k vlastnímu výkonu, obavy o dostatečnost vlastních schopností či obavy z důsledků vlastního selhání. Kognitivní složka testové úzkosti má vliv na jedince před úkolem, během úkolu i po něm (Cassady \& Johnson, 2002). Poznávací procesy se podílejí na vzniku strachu v mnoha ohledech: situace je považována za obtížnou a nebezpečnou, jedinec si nevěří, že situaci zvládne, zabývá se negativními důsledky, zabývá se tím, jak výsledek zhodnotí druzí, očekává neúspěch a negativní hodnocení od druhých, zvažuje nízkou úroveň svých schopností, obává se o přiměřenost svého chování, prožívá pocity nepřipravenosti na zkoušení a podobně.

Emocionalita (emocionality) představuje afektivní komponentu a odkazuje k vnímání autonomních reakcí, které jsou situací vyvolány. Váže se především na uvědomování si tělesných reakcí (vybuzení) a tenze spojených s typickými fyziologickými projevy (bušení srdce, nevolnost, závratě, pocení, panika, sucho v ústech). Odborné studie (Cassady \& Johnson, 2002; Hrabal, Man \& Pavelková, 1989; Schwarzer, Jerusalem \& Stiksrud, 1984) dokládají, že obě složky (obavy i emocionalita) působí na výkon poněkud odlišnou silou a podobou v jednotlivých fázích zkoušky. Očekávání neúspěchu před zkouškou je spíše ve vztahu $s$ pochybnostmi než s rozrušitelností. Čím větší jsou pochybnosti o vlastní kompetenci, tím menší je očekávání úspěchu. Intenzita pochybování o sobě se málo mění před zkouškou, $v$ jejím průběhu a po ní, rozrušení naproti tomu dosáhne při zkoušce svého vrcholu a pak prudce klesá. Výkon při zkoušce koreluje více s pochybnostmi (kognitivní složka strachu) než s rozrušením (emocionální složka strachu). Kognitivní i emocionální složka úzkosti od sebe mohou být rozlišeny psychometricky a mají rozdílné vztahy k výkonu (Stöber, 2004).

Novější výzkumy se shodují především v tom, že testová úzkost je svou povahou multidimenzionální. Některé multidimenzionální modely testové úzkosti (např́ḱlad Hodapp et al., 1995) navrhují 
vedle komponent obavy, emocionality a interference i komponentu nedostatku sebe-důvěry (self-efficacy) a další autoři výzkumně potvrzují existenci těchto čtyř komponent (Stöber, 2004). Dalš́i výzkumy však ukazují (Keith et al., 2003), že self-efficacy je sice silně spojena s testovou úzkostí, ale jde spíše o dva odlišné konstrukty. Právě analýza vztahu self-efficacy a testové úzkosti je jednou z podstatných otázek pro další výzkumy.

Klíčové rozlišení kognitivní a emocionální komponenty však nadále zůstává základní. Aby bylo možno empiricky ověřit dvě výše zmíněné komponenty testové úzkosti v praxi, vznikl nástroj, který je přesně zacílen na identifikaci obav a emocionality během testové situace. Spielberger et al. (1978) vyvinuli sebehodnoticí škálu TAI (Test Anxiety Inventory), která byla vytvořena pro měření obou faktorů testové úzkosti. Česká verze nástroje TAI vykazuje velmi kvalitní psychometrické vlastnosti, byla prokázána uspokojivá reliabilita i validita nástroje $\mathrm{v}$ podmínkách českého školství (Kubíková et al., 2018a). Postupně přicházely i jiné pohledy na teorii testové úzkosti. Jako vhodné se ukázalo využití modelů interference, které se zaměřovaly na postižení faktorů interferujících $s$ výkonem jedince během testu (obavy o výsledek, nedostatek pozornosti), a modelů deficitu, které poukazovaly na nějaký deficit $\mathrm{v}$ dovednostech jedince (nedostatečná př́prava, nedostatečné studijní předpoklady).

Modely interference předpokládají, že jedinec testovou látku dobře ovládá, ale něco v průběhu testu způsobuje, že dobrý výkon v testu nepodává, oslabuje se vybavování (využití) dříve naučeného. Autoři teorií interference analyzují zejména fázi samotné testové situace. Wineová (1971) se zaměřila na účinky testové úzkosti z hlediska pozornosti. Zjistila, že rozdíly ve výkonech souvisí s tím, na co při výkonu jedinec soustřed’uje pozornost. Jedinci $s$ testovou úzkostí rozdělují pozornost během plnění úkolu mezi vnitřní podněty jich samých (většinou jde o sebehodnoticí myšlenky) a podněty relevantní úkolu. Např́iklad se zabývají obavami o svůj výkon, přemýšlejí o tom, jak asi dopadnou ve srovnání s druhými, mívají pocity, že na úkol nestačí - na rozdíl od neúzkostných jedinců, kteří svou pozornost plně věnují úkolu.

I. G. Sarason (1984) rozlišil čtyři zdroje interference: obavy, irelevantní myšlenky, tenze, tělesné symptomy. Obavy (kognitivní složka) zahrnují starosti a zabývání se možným selháním a jeho př́ipadnými důsledky, včetně přemýšlení nad tím, jak si asi vedou ostatní. Obavy většinou doprovázejí dobu testu, ale i dobu před testem. K testu irelevantní myšlenky (kognitivní složka) představují přemýšlení o věcech, které $s$ testem nesouvisejí, jedinci se zabývají sami sebou a nekoncentrují se na úkol. Neúzkostní jedinci se zaměřují na úkol bez rušivých vlivů a mohou tak lépe využít své kapacity. Komponenta tenze (emocionální složka) vyjadřuje pocit napětí a emocionální rozladění v prủběhu testu, ale i před testem. Tělesnými symptomy (váží se také spíše na emocionální složku) se rozumí specifické tělesné reakce, které jedinec zažívá před testem, v prů- 
běhu testu, ale i po jeho skončení, např. nevolnost, sucho $\mathrm{v}$ ústech, třes, studené ruce, bušení srdce, pocení, bolesti hlavy, závrat'.

Modely deficitu vycházejí z předpokladu, že u úzkostných jedinců může být horší výkon způsoben dvěma druhy deficitu: špatnými studijními dovednostmi či návyky a deficitem $\mathrm{v}$ testových dovednostech. Zpochybňují tvrzení modelů interference v tom, že úzkostní studenti znají potřebnou látku, ale během testu si látku nejsou schopni vybavit. Výsledky výzkumů opírající se o modely deficitu (Culler \& Holahan 1980; Smith, Arnkoff \& Wright, 1990) ukazují, že horší výkon v testových situacích může být dán i nedostatečnými studijními dovednostmi, pečlivostí, mírou př́ípravy a podobně.

Vztah mezi zkouškovým strachem a výkonem není zcela jednoznačný. V laboratorních podmínkách při uměle vytvořených úkolech zaznamenáváme značný záporný vztah mezi strachem a výkonem, zatímco v přirozených výkonových situacích, např́iklad ve škole při prověrkách, se tato závislost výrazně snižuje. Vztah mezi strachem a výkonem se podstatně liší zvláště u žákủ úzkostných a neúzkostných - viz výše (Hrabal \& Pavelková, 2010; Pavelková et al., 2013). Tento nejednoznačný vztah mezi strachem a výkonem se zvláště projeví, posuzujeme-li výkon žáků jako jejich prospěch. Školní realita a školní zkouškové situace jsou velmi složité a jsou ovlivněny mimo jiné charakterem a kvalitou vyučování, osobností a vystupováním učitele a jeho postojem $\mathrm{k}$ úzkostným žákům. Některé výzkumy naznačují (Hagtvet, 1989), že styl založený na př́snosti, popřípadě nepřátelství, zřejmě zvyšuje míru prožívaného ohrožení žáků, a to zejména těch, kteří mají vysokou dispoziční úzkost. Proto ti učitelé, kteří používají $\mathrm{k}$ motivování výhrůžek a zastrašování, zesilují negativní vztah mezi zkouškovým strachem a školním výkonem u svých žáků. Ve špatně vedených třridách zkouškový strach zvyšuje úroveň vztahu schopností a školního výkonu. Žáci s nižšími rozumovými schopnostmi mají v těchto podmínkách málo možností vyrovnat se s požadavky školy účinnějším učením, protože mohou být více handicapovaní zkouškovou úzkostí (tamtéž). Svoji roli může sehrávat také postoj učitele $\mathrm{k}$ vlivu strachu na výkon. Tento postoj se může projevit i ve známkování. Učitelé, kteří jsou přesvědčeni, že strach podstatně znevýhodňuje úzkostné žáky, budou tyto žáky pravděpodobně známkovat mírněji než žáky neúzkostné. Učitelé, pro něž školní výkon v prvé řadě odráží schopnosti, naopak při známkování ohled na příznaky žákova strachu neberou („Bud' umí, nebo neumí, strach přeci nehraje roli.").

Je tedy zřejmé, že při hodnocení vztahu strachu a školního výkonu musíme u každého žáka brát v úvahu podmínky, v nichž výkon probíhá (situaci), charakter činnosti a především úroveň dispoziční úzkostnosti dítěte.

\section{STRACH V MOTIVAČNÍCH SOUVISLOSTECH}

Strach úzce souvisí s motivací. Různorodé faktory, které mají vliv na vykonávání 
činnosti, jsou považovány za determinanty úzkosti, ale zároveň za aspekty motivace (Jerusalem \& Liepmann \& Hermann, 1985). Vztah mezi úzkostí a motivací byl tematizován především $\mathrm{v}$ rámci teorií výkonové motivace. $S$ rozvojem jedincova $J a ́$ se rozvíjí řada potřeb, které jsou zdrojem činnosti a chování směrujících jednak $\mathrm{k}$ osamostatnění, potvrzení a prosazení $J a ́$, jednak k jeho obraně, je-li ohroženo. Připomeňme např́klad Atkinsonův model (Atkinson, 1964), který je založený na nezávislosti potřeby úspěšného výkonu a potřeby vyhnutí se neúspěchu. Obohacením diagnostických strategií uchopení strachu v rámci výkonové motivace bylo Schmaltovo rozlišení aktivního a pasivního strachu (Schmalt, 2005). V metodě LMG (Leistungs-Motivation-Gitter) jsou zachyceny dvě motivační tendence: tendence přibližžení se úspěchu (naděje na úspěch) a tendence vyhnout se neúspěchu (strach ze selhání). V rámci tendence vyhnout se neúspěchu je přitom rozlišována pasivní a aktivní forma strachu $\mathrm{z}$ neúspěchu (tamtéž).

Oba typy strachu (pasivní i aktivní) mají společné zaměření na ohrožující následky hrozícího neúspěchu, ale liší se na behaviorální a kognitivní úrovni. Jedinci s vysokou mírou pasivního strachu mají tendence $\mathrm{k}$ vyhýbavým strategiím; tendence unikat $\mathrm{z}$ hodnocených výkonových situací může být fyzická, ale i mentální (tamtéž). Tito jedinci bývají ve výkonových situacích neaktivní, bývají zaplaveni obavami o vlastní kompetenci. Obdobně jako obava $\mathrm{z}$ neúspěchu $\mathrm{v}$ Atkinsonově chápání je Schmaltem pasivní strach chá- pán jako inhibující proměnná. Aktivní forma strachu bývá spojována $s$ vyšším emocionálním prožíváním výkonových situací a anticipací hrozícího nebezpečí. Je chápána jako facilitující proměnná, která je aktivována jedincovou zdatností zvládat výzvy tak, aby nedošlo k selhání. Tito lidé se vyhýbají hrozícímu neúspěchu vynaložením větší snahy. Pasivní strach oslabuje výkon a potěšení z úkolu. Naděje na úspěch (pozitivní výkonová motivace) a aktivní strach mají podle Schmalta (tamtéž) na výkon pozitivní dopad, protože aktivují snahu jedince.

Obdobná zjištění, i když s dominantním pozadím neurofyziologickým, nacházímenapř.vGrayověteoriiRST(Reinforcement Sensitivity Theory; Gray, 1982), která je inspirovaná výzkumem lidského chování u dětí a dospělých. Gray (tamtéž) předpokládal existenci dvou regulativních typů chování (vyhýbající se versus přibližující se) v závislosti na podnětech z prostředí; tzv. systém BIS (Behavioral Inhibition System) a BAS (Behavioral Activation System). Aktivity chování jsou v systému BIS/BAS popisovány jako dva odlišné typy regulujícího chování.

Aktivační systém BAS a inhibiční systém BIS představují odlišné struktury nervového systému (Carver \& White, 1994). Pasivní strach je možné srovnat $s$ inhibičním systémem (BIS), kdy jsou aktivovány signály trestu a nezískání odměny a dochází $\mathrm{k}$ inhibici chování, větší náchylnosti $\mathrm{k}$ úzkosti či $\mathrm{k}$ depresivním poruchám. Tito jedinci při setkání s ohrožujícími či negativními situacemi zvýšeně zažívají strach, úzkost, frustraci a smutek. 
Aktivní strach můžeme srovnat $s$ aktivačním systémem (BAS), kdy je hrozba trestu odvrácena aktivním vyhnutím za pomoci vynaloženého úsilí. Aktivační systém BAS je citlivý na signály odměny, absenci trestu nebo únik z trestu. Tito jedinci bývají velmi zaměřeni na cíl a jeho dosažení, prožitek situace bývá doprovázen pocity naděje, očekávané radosti. Tato senzitivita se odráží ve větším vynaložení úsilí při činnosti, když je jedinec vystaven možnosti získat odměnu (tamtéž).

Výzkumné práce zabývající se RST zkoumaly dále vztah BIS/BAS k jednotlivým dimenzím osobnosti, a to zejména ve vztahu $\mathrm{k}$ temperamentu a míre neuroticismu. Studie prokázaly, že BIS reakce se pozitivně vážou $\mathrm{k}$ osobnostní dimenzi neurotičnosti a negativně $\mathrm{k}$ extroverzi, zatímco u BAS je tomu naopak, pozitivně se váže $\mathrm{k}$ extroverzi a negativně $\mathrm{k}$ neuroticismu (Muris et al., 2005a, 2005b). V současné době existují i odlišné konstrukty v chápání BIS. Někteří vědci (Corr, 2004; McNaughton \& Corr, 2008) předpokládají, že existují tři neurobiologické subsystémy, které jsou spojeny s aktivačně motivačními vlastnostmi osobnosti: behaviorální aktivační systém - BAS, behaviorální inhibiční systém - BIS a boj proti „zamrznutí“ v negativních reakcích - systém FFFS (Flight-Fight Freeze System).

McNaughton a Gray (2000) nově popisují BIS jako „obranný př́stup“, který je charakterizován následujícími stimuly: posouzení rizik a opatrnost (porovnej $s$ Grayovým dřívějším pojetím BIS jako pasivního vyhýbání) a nově zavádějí di- menzi FFFS (aktivní vyhýbání - útěk). BIS systém tedy nově řeší konflikt mezi BAS (pro aktivní přiblížení se) a FFFS (útěk). Podle McNaughtona a Graye (tamtéž) řešení konfliktů vždy upřednostňuje zapojení FFFS zvýšením intenzity negativních valencí vstupů do tohoto systému (tj. zvýšení vnímané intenzity ohrožení). Díky těmto reakcím je možné vysvětlit fakt, že jedinec má tendenci zbavit se úzkosti pomocí nějaké formy únikového chování.

Pro lepší pochopení mechanismu školního strachu a jeho podob je možné analyzovat také behaviorální a hormonální reakce organismu na stres, které se aktivují $\mathrm{v}$ př́ípadě nebezpečí. $\mathrm{V}$ posledních letech se středem pozornosti výzkumu v oblasti reakce člověka na stres stala analýza tzv. biomarkerů. Vycházejí z hypotézy, že psychický stres spouští hypotalamo-pituitárně-adrenální (HPA) osu a uvolňování kortizolu, který má vliv na typ reakce v ohrožující situaci. Kortizol je považován za hlavní biomarker ve výzkumu reakcí na stresové situace (Hellhammer, Wüst $\&$ Kudielka, 2009). Z výsledků provedených studií vyplývá, že pokud hodnotíme reakce organismu na zátěžové situace, je nutné brát v úvahu i tzv. copingové strategie (jakým způsobem jedinec obvykle reaguje na zátěžové situace a jak je zvládá), které jedinec $\mathrm{v}$ reakci na typ sociální situace využívá. Typ strategie, kterou zvolí, je pak odvislý zejména od zkušeností, které s podobnou situací měl, a od toho, jaké výsledky očekává v budoucnu v podobných situacích (Schultheiss, Wiemers \& Wolf, 2014). 
Fyziologické reakci organismu ve škole se podrobně věnoval výzkum realizovaný v letech 2017 a 2018 v České republice (Kubíková et al., 2018a, 2018b). Hlavním cílem výzkumu bylo zjistit, jak dospívající děti reagují na potenciálně zátěžové situace ve škole v HPA ose a zda reakce souvisí s úrovní rozvoje výkonové motivace a s osobnostním laděním jedince (neuroticismus). Zároveň výzkum ověřoval, zda je školní strach odlišný konstrukt než tzv. rysová úzkost a již dokumentovaná zjištění (Schultheiss et al., 2014), že výkonová orientace žáka má vliv na kortizolovou odpověd' po dominující výzvě či potenciálně stresujících úkolech (písemná práce). Výsledky studie ukazují, že převažující typ výkonové motivace souvisí s copingovými strategiemi zvládání stresu. Žáci $s$ vyšší potřebou úspěšného výkonu a nízkou tendencí k úzkostnému chování mají stabilnějš́i hladinu kortizolu významně nižší a častěji volí aktivní copingové strategie než žáci $s$ vyšší potřebou vyhnutí se neúspěchu a $s$ větší tendencí k úzkostnému chování. Výzkum též ukázal, že školní strach je poněkud odlišný konstrukt než tzv. rysová úzkost. A to pravděpodobně proto, že situace ve škole jsou specifické tím, že jsou často spojené se silnou hrozbou sociálního hodnocení, ze které jedinec nemá možnost uniknout, je nucen $\mathrm{v}$ této situaci setrvat a přizpůsobit se jí. Právě strategie zvládání stresových situací považujeme za podstatné.

Vedle pozornosti, která je v psychologii věnována vztahu mezi strachem a výkonovou motivací, je rozpracováván také vztah mezi strachem a flow motivací. Au- torem konceptu flow je Csikszentmihalyi (Csikszentmihalyi \& Hauserová, 1996). Využití (navození) flow motivace ve školním vyučování (v jednotlivých školních předmětech) však s sebou nese ještě mnoho nevyjasněných otázek. Prožitek typu flow, který je charakterizován bezproblémovým, hladkým plynutím činnosti, se zpravidla nevyskytuje u žáků prožívajících př́i práci na úkolech strach. Tato teoretická východiska se potvrzují i ve výzkumech Neudörflové (2017) a Vaníčkové (2014). Ukázalo se však, že facilitující testová úzkost neměla $s$ prožitkem flow negativní souvislost. Žáci s facilitující testovou úzkostí poměrně často pocitují před úkolem nervozitu, ta však není vtahována do samotné práce na úkolu (jakmile na úkolu začnou pracovat, na nervozitu „zapomenou“). Nervozita těmto žákům nebrání v podání dobrého výkonu. Dále se ukazuje, že žáci s pozitivní výkonovou motivací mají větší pravděpodobnost dostat se do prožitku flow než žáci se silnou potřebou vyhnutí se neúspěchu (Pavelková \& Dvořáková, 2015).

\section{UČENÍ A ÚZKOST}

Strach a testová úzkost nedopadají ve škole jen na samotnou testovou fázi, ale na celý proces učení. Zajímavým modelem $\mathrm{v}$ tomto ohledu je model zpracování informací (Tobias, 1985, 1986), který kombinuje aspekty modelu interference a modelů deficitu a rozeznává trri fáze procesu zpracování informací: input (fáze před zpracováním informací), zpracování (získané informace se nějakým způsobem 
zakódují a ukládají) a output (jedinec již informace zpracoval a má předvést, co se naučil). Testová úzkost může proces zpracování informací ovlivnit $v$ jedné fázi nebo ve více fázích. I u většiny dalších odborníků (Cassady, 2004; Zeidner 1998) zabývajících se dopadem úzkosti na proces učení nacházíme rozdělení do tří fází, které však nově zahrnují i fázi reflexe po testu: př́pravná fáze, fáze testového výkonu, reflektivní fáze. Př́ípravná fáze zahrnuje př́pravu na test, kdy úzkost může ovlivnit správné zakódování a uložení naučeného materiálu či volbu nevhodných strategií (opakované čtení, povrchní přístup, potíže s odlišením podstatných a méně podstatných částí učiva atd.).

Naveh-Benjamin, McKeachie a Lin (1987) hovoří v této souvislosti o dvou typech úzkostných žáků z hlediska studijních návyků. Zjistili, že vysoce úzkostní jedinci se špatnými studijními návyky vykazovali špatné výkony i v testových situacích, které nebyly hodnoceny, či při testu, na kterém pracovali doma. A problémy přenášeli i do dalších fází (fáze testového výkonu a fáze po testu). Kdežto vysoce úzkostní jedinci s dobrými učebními návyky, kteří nemají problém v kódování informací, mají problém v druhé fázi s vybavováním naučeného při testu. Jejich výkon se však zlepšil, pokud byl odstraněn tlak $\mathrm{z}$ hodnocení. $\mathrm{V}$ reflektivní fázi, která po testu může podstatně ovlivnit další fázi testové př́pravy, jde především o atribuční tendence jedince. Úzkostní žáci, kteří mají sklon hledat příčiny svých neúspěchů $v$ těžko změnitelných vnitřních př́icinách (nedostatečných schopnostech) nebo vnějších př́ícinách, které nemají pod kontrolou (obtížnost úkolu, nespravedlnost hodnocení), mají tendenci své úspěchy devalvovat, protože jejich př́činy vidí v náhodě (štěstí). Tyto neštastné atribuční tendence mohou vést k vyhýbání se testovým situacím a prožitkům bezmocnosti (Bandura, 1989; Cassady, 2004).

Strach ve škole ovlivňuje také úroveň strukturovanosti požadavků. Ukazuje se, že úzkostné děti dosahují horších výkonů než děti neúzkostné, jestliže je učební situace málo strukturovaná. Důležitou roli ve vztahu strukturovanost situace, úzkostnost a výkon hrají i schopnosti. Strukturované požadavky velmi pravděpodobně prospívají spíše úzkostným žákům $s$ nadprůměrnými a průměrnými schopnostmi. Naopak úzkostní žáci $s$ nízkými schopnostmi se cítí díky rozpracovanému učebnímu materiálu přetěžováni a mohou reagovat s odporem. Neúzkostným a málo schopným žákům však strukturovaný materiál vyhovuje, neúzkostným a schopným žákům bude málo strukturovaný materiál nejspíše také vyhovovat, strukturu si sami vytvoří (Krohne, 1996). Rovněž prŕíprava na zkouškovou situaci (ve škole tedy především domácí příprava) silně ovlivňuje vztah zkouškového strachu a výkonu při zkoušení. Do jisté míry lze překonávat „dezorganizujícíc účinek strachu na naučené tím, že úzkostné dítě věnuje více času a úsilí prŕípravě (Hagtvet, 1989; Man \& Hrabal, 1989). Strukturovanost učební látky (požadavků) a možnost př́ípravy (připravenost) představují pravděpodob- 
ně předpoklady, na jejichž základě mohou úzkostné osoby kompenzovat negativní vliv strachu na výkon.

\section{OSOBNOST ÚZKOSTNÉHO ŽÁKA}

Úzkost můžeme chápat jako faktor „osobní zranitelnosti“". Tendence $\mathrm{k}$ vnímání úzkosti se individuálně odlišuje, závisí na mnoha faktorech hereditárních i sociálních (podrobnější pohled na vznik a průběh úzkosti můžeme nalézt např. u Balcara, Vymětala, ze zahraničních autorů zejména u Schmalta a Sarasona). Pochopit chování individuí s vysokou motivací vyhnout se neúspěchu můžeme pomocí následujícího zjištění.

„Osoba s vysokou tendencí $\mathrm{k}$ prožívání úzkosti je náchylná k obranným strategiím, jakými jsou např. vyhýbání se situacím, kde může být konfrontována s kritickými názory, nebo takovým činnostem, kde je možné očekávat jakékoli hodnocení (vnímá ho jako hrozbu). Vysoce úzkostní lidé mají tendenci se neustále strachovat, mají chabá očekávání, interpretují jakékoli známky fyziologického vzrušení jako indikátory úzkosti. Zpětnou vazbu ke svému výkonu chápou jako hodnocení své osobnosti jako celku a hodnocení neúspěchu reflektují více než hodnocení úspěchu." (Schwarzer \& Jerusalem, 1992). Schwarzer a Jerusalem (tamtéž) byli přesvědčeni, že pocit bezmocnosti je důsledkem dlouhotrvajícího a soustavného prožívání pocitů neschopnosti. Z tohoto důvodu popsali potenciální vývoj ztráty kontroly nad danou situací a vznik pocitu osobní bezmocnosti. Tyto situace jsou běžné zejména ve školním prostředí, kde může být jedinec jak úspěšný, tak neúspěšný.

Wilson a Brazendale (1973) dokázali, že existují jisté genetické faktory a faktory prostředí, které vedou $\mathrm{k}$ subjektivně prožívanému pocitu nejistoty a $\mathrm{k}$ nízkému sebehodnocení. Jedinci s nízkým sebehodnocením podle nich chápou prostředí, ve kterém se nacházejí, jako komplexní, proměnlivý a zrádný faktor a reagují na veškeré změny bázlivě a nejistě, protože jim chybí vědomí vlastní schopnosti ovlivňovat události kolem sebe či konat autonomní rozhodnutí v souladu se svým přesvědčením (Schwarzer \& Quast, 1985).

Vnímaná self-efficacy se v mnoha výzkumech potvrzuje jako podstatný faktor pojící se s výkonem žáků (Bandura, 1989). Vyšší self-efficacy je pozitivně spojováno i s průběhem žákovské práce a $s$ prožíváním hodnoticích situací. Důvěra $\mathrm{v}$ sebe statisticky vysoce významně souvisí i s nižší testovou úzkostí. Žáci, kteří více veří ve své schopnosti, se při testech cítí lépe, nepocitují tolik tělesných symptomů úzkosti, mají méně problémů s efektivním myšlením a méně $\mathrm{k}$ testům irelevantních myšlenek a obav (včetně sociálních obav). Cítí se během testů uvolněněji a nemají tolik potíži s pozorností a pamětí (Neudörflová, 2017; Pavelková \& Dvořáková, 2015; Pavelková \& Tauchmanová, 2013). Vedle zmíněné snížené self-efficacy jsou u úzkostných dětí zaznamenávány potíže $s$ pozorností v důsledku strachu. Úzkostné děti musí věnovat delší dobu př́ípravě na situace zkoušení (př́ípadně i vyučování), nebot' sám strach na sebe soustředí 
velkou část pozornosti dítěte věnované celkové době na př́pravu. Úzkostné děti jsou zaměstnávány rušivými myšlenkami typu „To se nemůžu nikdy naučit“, „Co se stane, když neuspěju?“, „Udělám si ostu$\mathrm{du}$ “ a v neposlední řadě emocionálním vzrušením „Ted” se asi červenám“, „Cítím, jak mi buší srdce“.

Pro úzkostné žáky jsou př̀ práci na výkonovém úkolu typické ještě další př́iznaky. Je pravděpodobné, že mají již od samého počátku procesu zpracování informací potíže s optimálním rozčleněním materiálu. Většina učitelů si jistě všimla toho, že řada úzkostných dětí ze strachu, že se nenaučí všechno, co se mají naučit, těžko rozeznává důležité od nedůležitého. Úzkostní jedinci mnohdy přehližejí některé významné znaky při zpracování úkolu a zpočátku přistupují k úkolovým situacím spíše povrchně (učí se vše na stejné úrovni), na rozdíl od neúzkostných dětí, které jsou schopny od počátku zpracovat informace na „hlubší“ úrovni, jsou ochotny jít do většího rizika, že něco přeskočí, a dávají důraz na podstatnější části učiva (Man, Stuchlíková \& Hagtvet, 1992). Úzkostné děti mívají také větší potíže při rozhodování. To se projevuje již ve zmíněných problémech (vnitřní nejistotě), mají-li rozhodnout o důležitosti informací apod. Úzkostní jedinci ve srovnání s neúzkostnými mívají také méně efektivní techniky (styly) studia, které mohou plynout i z obtíží při rozhodování.

Další z otázek, kterou si ve školním prostředí můžeme položit, je, zda žáci, kteří mají strachem zatížený postoj k jed- notlivým školním předmětům, prožívají $\mathrm{v}$ těchto předmětech také strach $\mathrm{v}$ konkrétních úkolech. Otázku souvislosti žákovského strachu v matematické úkolové situaci v doméně matematiky řešila např̀ Neudörflová (2017). Souvislost byla potvrzena. Ukazatele strachu v úkolové situaci (výkonové obavy, rušivé myšlenky) vykazovaly statisticky významné vazby $s$ ukazateli strachu $v$ doméně předmětu matematika. Strach se u žáků v matematice ukazuje spíše jako stabilní charakteristika.

\section{ZÁVĚR}

Strach v lidském životě je téma, kterému je věnována velká pozornost $\mathrm{v}$ zahraničí, ale i v České republice, přesto však zůstává mnoho otázek nedořešených. $Z$ velice širokého a komplikovaného tématu strachu v lidském životě jsme vybrali jen oblast školního strachu, konkrétně jsou analyzovány souvislosti mezi strachem a školním výkonem, respektive dopady strachu na učení. Zdaleka tím nepokrýváme ani celé téma školního strachu. Možný rozsah stati nám neumožňuje pojednat šíreji například o sociálním strachu, strachu z fyzického či psychického ublížení vrstevníky a podobně. $V$ článku podrobně nepředstavujeme ani diagnostické nástroje zachycující školní strach a metody překonávání strachu. Zvláště strategie zvládání strachu považujeme pro učitele za velmi důležité, protože strategie překonávání strachu mohou být jak efektivní, tak neefektivní. Žák si je může osvojovat spontánně (na- 
př́klad nápodobou od vrstevníků) nebo pod vedením dospělých (učitelů, rodičů, terapeutů), jde však o velmi rozsáhlou problematiku, která vyžaduje i hlubší výzkumná šetření, proto se těmto otázkám budeme věnovat $\mathrm{v}$ dalších statích.

Článek má spíše výběrově přehledový charakter, s oporou o dosavadní výzkumná zjištění ukazuje, jak komplikované a široké je téma strachu ve škole. Nejde jen o variabilitu vztahu úzkost-výkon v souvislosti s různými konstelacemi školních situací vyvolávajících strach a strachem jako osobnostním rysem (kdy strach posiluje, respektive oslabuje školní výkon). Zvýšená pozornost byla v stati věnována analýze kognitivní stránky strachu (pozornostní deficity, zaměření na Já, očekávání, kauzální atribuce a hodnocení ohrožení) i emocionální a motivační složky strachu. Z hlediska motivačního byla zdůrazněna úzká návaznost na výkonovou motivaci.

Jednoznačně nejde ani odpovědět na otázku, zda strach do školy patř́i, či nepatří. $V$ článku zdůrazňujeme negativní dopady strachu na školní práci, a to především, když se strach stane osobnostním rysem. Zároveň se potvrzuje, že strach v podobě určitého tlaku na žáky může být motivačním činitelem a může napomoci rozvoji aktivních copingových strategií, jak na strach (zátěž) reagovat. $\mathrm{Z}$ tohoto hlediska je možné asociovat časté diskuse (převážně laické) z posledních let v České republice, ale i v zahraničí, v nichž se upozorňuje, že generace vyrůstající jen $\mathrm{v}$ „pozitivní výchově, pracující hlavně s odměnami“ je v dospívání a při nástupu do zaměstnání trochu přecitlivělá (těžko se vyrovnává $s$ kritikou či upozorněním na chybu apod.). Nabízí se také otázka, zda se snížení typického školního strachu (špatné známky, obava, že se nedostanu na střední školu) nepřesouvá do jiných podob strachu (např́klad strach, že se nepřinutím učit). Hlubší analýzu by zasloužila i otázka, zda snížení strachu u dětí se nepřelilo do zvýšení nudy žáků. $\mathrm{K}$ těmto provokativním úvahám však nemáme dostatek podkladů, a tak jsou míněny jen jako podnět k zamyšlení.

Pro další analýzy je možné doporučit multivariační charakter výzkumů. Složitost školní reality zvýrazňuje nutnost situování výzkumů do přirozeného školního prostředí. Je nutné analyzovat příciny vzniku strachu i jeho důsledky, odhalovat mechanismy, které jej udržují při životě, a pracovat $s$ úzkostnými dětmi na snížení jejich úzkosti. Školní strach a úzkost je velmi složitý fenomén, který se může u jedinců projevovat různě. $S$ tím bychom měli počítat i při intervencích a doporučeních. Potíže každého konkrétního úzkostného žáka mohou být jiné.

Doporučujeme výzkumně pokračovat i se školním strachem $\mathrm{v}$ širších motivačních souvislostech zahrnujících i biodromální pohled. Motivační tendence (především ty, které jsou orientované na úspěch) mohou být zakotveny v dlouhodobých cílech, ale i vztahování se $\mathrm{k}$ budoucnosti může být spojeno $s$ nejrůznějšími obavami. Souvislostmi mezi strachem a časovou orientací žáků 
a obavami žáků do budoucnosti se již některé práce zabývají (Vitošková \& Pavelková, 2018; High, 2013). Za důležitou považujeme i analýzu balancované časové perspektivy vzhledem k prožitku strachu a volbě copingových strategií v krátkodobých, respektive dlouhodo- bých úkolech (Pavelková \& Urbanová, 2018; Urbanová, 2016).

Slova na závěr: Školní strach je důležité téma, dlouhodobě nezvládnutý školní strach může nejen ovlivňovat školní výkony, ale souvisí i s kvalitou života člověka.

\section{LiTERATURA}

Alpert, R., \& Haber, R. N. (1960). Anxiety in academic achievement situations. The Journal of Abnormal and Social Psychology, 61(2), 207-215.

Atkinson, J. W. (1964). An introduction to motivation. Princeton, NJ: Van Nostrand.

Bandura, A. (1989). Human agency in social cognitive theory. American Psychologist, 44(9), $1175-1184$.

Carver, C. S., \& White, T. L. (1994). Behavioral inhibition, behavioral activation, and affective responses to impending reward and punishment: The BIS/BAS scales. Journal of Personality and Social Psychology, 67(2), 319-333.

Cassady, J. C. (2004). The influence of cognitive test anxiety across the learning-testing cycle. Learning and Instruction, 14(6), 569-592.

Cassady, J. C., \& Johnson, R. E. (2002). Cognitive test anxiety and academic performance. Contemporary Educational Psychology, 27(2), 270-295.

Corr, P. J. (2004). Reinforcement sensitivity theory and personality. Neuroscience \& Biobehavioral Reviews, 28(3), 317-332.

Culler, R. E., \& Holahan, C. J. (1980). Test anxiety and academic performance: The effects of study-related behaviors. Journal of Educational Psychology, 72(1), $16-20$.

Csikszentmihalyi, M., \& Hauserová, E. (1996). O štéstí a smyslu života: Můžeme ovládat své prožitky a ovlivñovat jejich kvalitu? Praha: Lidové noviny.

Drvota, S., \& Plzák, M. (1971). Úzkost a strach. Praha: Avicenum.

Gray, J. A. (1982). Précis of the neuropsychology of anxiety: An enquiry into the functions of the septo-hippocampal system. Behavioral and Brain Sciences, 5(3), 469-484.

Hagtvet, K. A. (1989). The construct of test anxiety: Conceptual and methodological issues. Bergen/London: Sigma Forlag / Jessica Kingsley.

Hagtvet, K. A., Man, F., \& Sharma, S. (2001). Generalizability of self-related cognitions in test anxiety. Personality and Individual Differences, 31(7), 1147-1171.

Hellhammer, D. H., Wüst, S., \& Kudielka, B. M. (2009). Salivary cortisol as a biomarker in stress research. Psychoneuroendocrinology, 34(2), 163-171.

Hembree, R. (1988). Correlates, causes, effects, and treatment of test anxiety. Review of Educational Research, 58(1), 47-77. 
High, R. (2013). Diagnostika časové perspektivy u středoškolské mládeže (Disertační práce). Praha: Univerzita Karlova, Pedagogická fakulta.

Hodapp, V., Glanzmann, P. G., \& Laux, L. (1995). Theory and measurement of test anxiety as a situation-specific trait. In C. D. Spielberger \& P. R. Vagg (Eds.), Series in clinical and community psychology. Test anxiety: Theory, assessment, and treatment (s. 47-58). Washington, DC: Taylor \& Francis.

Honzák, R. (1995). Strach, tréma, úzkost a jak je zvládat. Praha: Maxdorf.

Hrabal, V., Man, F., \& Pavelková, I. (1989). Psychologické otázky motivace ve škole. Praha: Státní pedagogické nakladatelství.

Hrabal, I., \& Pavelkova, V. (2010). Jaký jsem učitel. Praha: Portál.

Jerusalem, M., Liepmann, D., \& Hermann, C. (1985). Test anxiety and achievement motivation: An analysis of causal relationships. Advances in Test Anxiety, 4, 135-138.

Keith, N., Hodapp, V., Schermelleh-Engel, K., \& Moosbrugger, H. (2003). Cross-sectional and longitudinal confirmatory factor models for the German Test Anxiety Inventory: A construct validation. Anxiety, Stress \& Coping, 16(3), 251-270.

Kubíková, K., Boháčová, A., Lukavská, K., Mainz, D., \& Svobodová, S. (2018a). Test Anxiety Inventory (TAI): Validization and psychometric properties of Czech version. Intcess 2018 - 5th International Conference on Education and Social Sciences, Dubai (s. 167-175).

Kubíková, K., Pavelková, I., Škaloudová, A., Lukavská, K., \& Svobodová, S. (2018b). Measuring behavioral inhibition and behavioral activation in children-validation of Czech BIS/ BAS scale. Polskie Forum Psychologiczne, 23(3), 43-60.

Krohne, H. W. (1996). Angst und Angstbewältigung. Stuttgart: Kohlhammer.

Lazarus, R. S. (1991). Emotion and adaptation. New York: Oxford University Press.

Liebert, R. M., \& Morris, L. W. (1967). Cognitive and emotional components of test anxiety: A distinction and some initial data. Psychological Reports, 20(3), 975-978.

Man, F., \& Hrabal, V. (1989). Self-concept of ability, social consequences, anxiety, and attribution as correlates of action control. In F. Halisch \& J. van den Bercken (Eds.), International perspectives on achievement and task motivation (s. 309-316). Amsterdam: Swets \& Zeitlinger.

Man, F., Stuchlíková, I., \& Hagtvet, K. A. (1992). The effects of cognitive interference and experimentally manipulated failure on information processing in a complex strategic game. Advances in Test Anxiety Research, 7, 332-343.

Mandler, G., \& Sarason, S. B. (1952). A study of anxiety and learning. The Journal of Abnormal and Social Psychology, 47(2), 166-173.

McNaughton, N., \& Corr, P. (2008). The neuropsychology of fear and anxiety: A foundation for Reinforcement Sensitivity Theory. In P. Corr (Ed.), The Reinforcement Sensitivity Theory of personality (s. 44-94). Cambridge: Cambridge University Press. 
McNaughton, N., \& Gray, J. A. (2000). Anxiolytic action on the behavioural inhibition system implies multiple types of arousal contribute to anxiety. Journal of Affective Disorders, 61(3), 161-176.

Muris, P., Meesters, C., de Kanter, E., \& Timmerman, P. E. (2005a). Behavioural inhibition and behavioural activation system scales for children: Relationships with Eysenck's personality traits and psychopathological symptoms. Personality and Individual Differences, 38(4), 831-841.

Muris, P., Roelofs, J., Rassin, E., Franken, I., \& Mayer, B. (2005b). Mediating effects of rumination and worry on the links between neuroticism, anxiety and depression. Personality and Individual Differences, 39(6), 1105-1111.

Naveh-Benjamin, M., McKeachie, W. J., \& Lin, Y.-G. (1987). Two types of test-anxious students: Support for an information processing model. Journal of Educational Psychology, 79(2), 131-136.

Neudörflová, B. (2017). Kognitivni, emocionálni a behaviorálni dimenze strachu v úkolových situacích v matematice (Rigorózní práce). Praha: Univerzita Karlova, Pedagogická fakulta.

Pavelková, I. (2002). Motivace žáků k učeni: Perspektivni orientace žákủ a časový faktor v žákovské motivaci. Praha: Pedagogická fakulta UK.

Pavelková, I., \& Dvořáková, I. (2015). Motivace v úkolové situaci. Pedagogika, 65(1), 34-56.

Pavelková, I., Stuchlíková, I., Škaloudová, A., Kubíková, K., \& Man, F. (2013) Vztahové normy učitele a jejich vliv na výkonovou motivaci žáků. In J. Jošt, F. Man \& A. Nohavová et al., Podpora zdravého psychického vývoje (s. 56-84). Praha: Eduko.

Pavelková, I, \& Tauchmanová, E. (2013). Motivace v diskurzu učitelů matematiky na 2. stupni základní školy. In M. Rendl et al., Kritická mista matematiky na základni škole očima učitelü. Praha: Pedagogická fakulta UK.

Pavelková, I., \& Urbanová, D. (2018). Nuda v edukačním kontextu: Teoretické konceptualizace a výzkumné metody. Československá psychologie, 62(4), 350-365.

Sarason, I. G. (1984). Stress, anxiety, and cognitive interference: Reactions to tests. Journal of Personality and Social Psychology, 46(4), 929-986.

Schmalt, H. D. (2005). Validity of a short form of the Achievement-Motive Grid (AMG-S): Evidence for the three-factor structure emphasizing active and passive forms of fear of failure. Journal of Personality Assessment, 84(2), 172-184.

Schultheiss, O. C., Wiemers, U. S., \& Wolf, O. T. (2014). Implicit need for achievement predicts attenuated cortisol responses to difficult tasks. Journal of Research in Personality, $48,84-92$.

Schwarzer, R., \& Jerusalem, M. (1992). Advances in anxiety theory: A cognitive process approach. Advances in Test Anxiety Research, 7, 2-31.

Schwarzer, R., Jerusalem, M., \& Stiksrud, A. (1984). The developmental relationship between test anxiety and helplessness. Advances in Test Anxiety Research, 3, 73-79. 
Schwarzer, R., \& Quast, H. (1985). Multidimensionality of the anxiety experience: Evidence for additional components. Advances in Test Anxiety Research, 4, 3-15.

Smith, R. J., Arnkoff, D. B., \& Wright, T. L. (1990). Test Anxiety and Academic Competence: A comparison of alternative models. Journal of Counseling Psychology, 37(3), 313-321.

Spielberger, C. D., Gonzalez, H. P., Taylor, C. J., Algaze, B., \& Anton, W. D. (1978). Examination stress and test anxiety. Stress \& Anxiety, 5, 167-191.

Stöber, J. (2004). Dimensions of test anxiety: Relations to ways of coping with pre-exam anxiety and uncertainty. Anxiety, Stress \& Coping, 17(3), 213-226.

Tobias, S. (1985). Test anxiety: Interference, defective skills, and cognitive capacity. Educational Psychologist, 20(3), 135-142.

Tobias, S. (1986). Anxiety and cognitive processing of instruction. In R. Schwarzer (Ed.), Self-related cognitions in anxiety and motivation (s. 35-55). Hillsdale, NJ: Lawrence Erlbaum Associates.

Urbanová, D. (2016). Časová perspektiva a nuda (Bakalářská práce). Praha: Univerzita Karlova, Pedagogická fakulta.

Vaníčková, M. (2014). Prožitek flow a zaujeti úkolem v hodinách německého jazyka (Bakalářská práce). Praha: Univerzita Karlova, Pedagogická fakulta.

Vitošková, V., \& Pavelková, I. (2018). Vztah žáků k budoucnosti. Lifelong Learning - celoživotni vzdèlávání, 6(3), 53-80.

Vymětal, J. (2004). Úzkost a strach u dètí: Jak jim predcházet a jak je překonávat. Praha: Portál. Wilson, G. D., \& Brazendale, A. H. (1973). Social attitude correlates of Eysenck's personality dimensions. Social Behavior and Personality, 1(2), 115-118.

Wine, J. (1971). Test anxiety and direction of attention. Psychological Bulletin, 76(2), 92-104. Zeidner, M. (1998). Test anxiety: The state of the art. New York: Springer.

doc. PhDr. Isabella Pavelková, CSc.

Katedra psychologie, Pedagogická fakulta Univerzity Karlovy;

e-mail: isabella.pavelkova@pedf.cuni.cz

Mgr. Katerina Kubiková, Ph.D.

Katedra psychologie, Fakulta pedagogická Západočeské univerzity v Plzni;

e-mail:kubikovk@kps.zcu.cz

Mgr. Aneta Bohácová

Katedra psychologie, Fakulta pedagogická Západočeské univerzity v Plzni;

e-mail:AnetaBo@seznam.cz 


\section{PAVELKOVÁ, I., KUBÍKOVÁ, K., BOHÁČOVÁ, A. Fear and School Achievement}

The article introduces the issue of fear and mainly focuses on the relationship between pupil's fear and school achievement, particularly on the impact of fear on learning. Structural and process approaches to fear and test anxiety (fear components) are analysed. We focus on models of interference and models of deficit and anxiety issues in the learning process, anxiety in relations to pupil's personality, and the differentiation of anxiety into facilitating and debilitating. Attention is focused on the evaluation (processing) of fear by the individual. The key question we are trying to solve is how much fear fosters or weakens school achievement. Marginally, we also analyse the related constructs of fear, motivational and volitional characteristics of pupils.

Keywords: psychology of education, fear and anxiety, test anxiety, components of fear, fear and learning, motivation. 